Ege Tıp Dergisi / Ege Journal of Medicine 2016;55(3):146-148

\title{
Motor nöropati ile başvuran geç başlangıçlı sistemik lupus eritematozus olgusu
}

\author{
A case of late-onset systemic lupus erythematosus presenting with motor neuropathy \\ Gökhan Sargın $^{1} \quad$ Taşkın Şentürk $^{1} \quad$ İrfan Yavaşoğlu ${ }^{2}$ Hüseyin Baygın ${ }^{3}$ \\ ${ }^{1}$ Adnan Menderes Üniversitesi Tıp Fakültesi, Romatoloji Bilim Dalı, Aydın, Türkiye \\ ${ }^{2}$ Adnan Menderes Üniversitesi Tıp Fakültesi, Hematoloji Bilim Dalı, Aydın, Türkiye \\ ${ }^{3}$ Adnan Menderes Üniversitesi Tıp Fakültesi, İç Hastalıkları Anabilim Dalı, Aydın, Türkiye
}

\section{Öz}

Sistemik lupus eritematozus (SLE) genellikle doğurganlık çağındaki kadınları etkilemekle birlikte, 50 yaş üzerinde SLE hastaları da bildirilmiştir. Bu hastalar, klinik başlangıç, tedaviye yanıt ve prognoz açısından farklııklar göstermektedir. Motor nöropatinin olması geç başlangıçı SLE hastalarında oldukça nadir görülen bir tutulum olup, yaşam kalitesini önemli ölçüde etkilemektedir. Hematolojik anormallikler SLE' de yaygındır, hemolitik anemi, lökopeni ve trombositopeni gibi sitopeniler için geç başlangıç ile erken başlangıç arasında anlamlı bir farklılık bulunmamaktadır. Bu yazıda, 68 yaşında motor nöropati ve hemolitik anemi ile başvuran ve geç başlangıçlı SLE tanısı koyduğumuz bir hastayı sunmayı amaçladık.

Anahtar Sözcükler: Polinöropati, lupus eritematozus, sistemik, yetişkin başlangıçlı.

\section{Abstract}

Systemic lupus erythematosus (SLE) usually affects women during their reproductive period, while SLE patients diagnosed over 50 years of age were also reported. Clinical onset, response to the treatment and prognosis vary in these patients. Motor neuropathy is a rare condition for late-onset SLE and it affects the quality of life significantly. Hematologic abnormalities are common in SLE and there is no significant difference between early-onset and lateonset for cytopenias such as hemolytic anemia, leukopenia and thrombocytopenia. Herein, we report a 68-year-old female patient presenting with motor neuropathy and hemolytic anemia who was diagnosed as late-onset SLE.

Keywords: Polyneuropathy, lupus erythematosus, systemic, adult-onset.

\section{Giriş}

Sistemik lupus eritematozus (SLE) etiyolojisi tam olarak bilinmeyen, otoantikor ve immun kompleksler aracılığıyla, hücre ve organ hasarına yol açan kronik, enflamatuvar, multisistemik bir hastalıktır (1). Hastalık genellikle doğurganlık çağındaki kadınlarda görülür. Bu yaşlarda görülme nedeni hormonal durumlara bağlanmıştır. Alevlenmelerin gebelikte artması, oral kontraseptif veya hormon replasman tedavisi alan kadınlarda SLE gelişim riskinin 1.2-2 kat artmış olması da bu durumu açıklamaktadır $(1,2)$.

İleri yaş başlangıçlı SLE 50-65 yaş sonrası hastalar için belirtilmiştir ve lupuslu hastaların \%2-20'sini oluşturmaktadır (1,2). Menopoz ve yaşlanma ile hücresel immünitedeki değişiklikler yaşı erişkinlerde SLE gelişimine katkıda bulunur (3).

\footnotetext{
Yazışma Adresi: Gökhan SARGIN

Adnan Menderes Üniversitesi Tıp Fakültesi, Romatoloji Bilim Dalı, Aydın, Türkiye
}

Makalenin Geliş Tarihi: 07.04.2015

Kabul Tarihi: 27.06.2015
Biz burada, motor nöropati bulguları ile polikliniğimize başvuran ve geç başlangıçlı SLE tanısı konulan 68 yaşındaki bir kadın hastayı nadir özellikleri nedeniyle sunmayı amaçladık.

\section{Olgu Sunumu}

Altmış sekiz yaşında kadın hasta halsizlik ve bilateral alt ekstremitelerde güçsüzlük yakınmasıyla kliniğimize başvurdu. Sigara ve alkol kullanım öyküsü olmayan hasta hipertansiyon nedeniyle irbesartan/hidroklorotiazid kullanmaktaydı. Özgeçmişinde SLE'ye ait belirtiler yoktu. Fizik muayenesinde; genel durumu iyi, konjunktivalar soluk, skleralar subikterik olup diğer sistem bulguları olağandı.

Laboratuvar değerlendirmesinde hemoglobin: $7.4 \mathrm{~g} / \mathrm{dL}$, ortalama eritrosit volümü: $99.6 \mathrm{fL}$, lökosit: $5.26 \times 10^{3} / \mathrm{mkrL}$, lenfosit: $0.8 \times 10^{3} / \mathrm{mkrL}$, trombosit: $388.000 / \mathrm{mkrL}$, retikülosit: $\% 8.9$, eritrosit sedimantasyon hızı: $47 \mathrm{~mm} / \mathrm{h}$ ve C-reaktif protein: $0.51 \mathrm{mg} / \mathrm{L}$ idi. İndirekt bilurubin: $1.8 \mathrm{mg} / \mathrm{dL}$, direkt bilurubin: $0.88 \mathrm{mg} / \mathrm{dL}$, LDH: $269 \mathrm{U} / \mathrm{L}$, direkt Coombs pozitif $(+4)$, haptoglobulin $<7.4$ 
$\mathrm{mg} / \mathrm{dL}$ olup kemik iliği aspirasyonunda eritrositer seride hiperplazi gözlendi. Böbrek fonksiyon testleri ve tam idrar analizi normal sınırlardaydı. Hepatit göstergeleri negatif, antinükleer antikor (ANA) 1/1000 titrede homojen + granüler paternde (nükleozom +; SS-A + ; dsDNA ++), antikardiolipin $\mathrm{lgG} / \mathrm{M}$ negatif, C3: $77.6 \mathrm{mg} / \mathrm{dL}, \mathrm{C} 4: 11.5$ $\mathrm{mg} / \mathrm{dL}$ idi. Protein elektroforezinde poliklonal bir artış saptandı. Akciğer grafisi ve abdominal ultrasonografi bulguları normal sınırlardaydı. Bilateral alt ekstremitelerde güçsüzlüğü olan hastanın elektromiyogramda her iki alt ekstremitede motor polinöropati olduğu gözlendi. Lumbosakral manyetik rezonans görüntülemede diskopati gözlenmedi ve nöral foramenler açık saptandı.

Mevcut bulgularla hastaya SLE tanısı konuldu ve 1 $\mathrm{mg} / \mathrm{kg} / \mathrm{gün}$ dozda steroid ve hidroksiklorokin $400 \mathrm{mg} / \mathrm{gün}$ başlandı. Takiplerinde hemoglobin $11.5 \mathrm{~g} / \mathrm{dL}$, indirekt bilurubin $1.24 \mathrm{mg} / \mathrm{dL}$, laktat dehidregenaz: $154 \mathrm{U} / \mathrm{L}$, retikülosit \% 1.4 olan ve şikayetleri gerileyen hasta 3 . ayda polikliniğimizde takip edilmektedir.

Hastadan tıbbi verilerinin yayınlanabileceğine ilişkin yazılı onam belgesi alındı.

\section{Tartışma}

Yaşlı ve genç hastalarda, hastalığın farklı genetik etkileri olabileceği ve farklı mekanizmalar ile yanıt verebileceği öne sürülmüştür (3). Yaşlanma ile birlikte immun sistemde patojenlere karşı savunma yeteneği azalırken, otoantijenlere yanıtta artma görülebilir (3). Yaşlanma sırasında, CD45RA+ T- lenfositler azalır, CD45RO+ Tlenfositler artar, CD28 reseptör eksprese eden CD4+ ve CD8+ T-lenfositler arasındaki oran değişir ve periferik kanda mitojen uyarımı sonrası prolifere olan lenfosit sayısı azalır $(3,4)$. Bu değişiklikler, atipik bulgularının oluşmasına yol açabilir. Yaşlılarda ilaç ilişkili lupus olasılığı açısından asebutolol, prokainamid, hidralazin, izoniazid, metil-dopa, karbamazepin vb. ilaçlar da dikkatle sorgulanmalıdır.

Geç başlangıçlı SLE klinik seyri daha iyi huylu olarak kabul edilir. Birçok yazara göre cilt bulguları, fotosensitivite, artrit, nörolojik tutulum ve nefrit daha az sıklıkla görülmektedir (1-3). İleri yaşta başlayan lupus hastalarında organ hasarı dikkatlice değerlendirilmelidir. Hastalık alevlenmelerine bağlı hastanede yatış gereksinimleri de genç hastalara göre daha azdır $(2,3)$. Erken ve geç başlangıçlı SLE hastalarının genel özellikleri Tablo-1'de gösterilmiştir. Bizim hastamızda hematolojik, immünolojik tutulum ve motor nöropati dışında herhangi bir diğer organ tutulumu gözlenmedi.

Geç başlangıçlı SLE'de periferik nöropati \%9 oranında bildirilmiştir (5). Periferik sinir sistemi tutulumu hastalığın geç özelliği olarak kabul edilir. Özellikle santral sinir sistemi tutulumu olan ve hastalık aktivitesi yüksek hastalarda daha sık gözlenir (6). Hafif distal, simetrik sensorimotor veya duyusal nöropati ve daha az oranda şiddetli, semptomatik mononöritis multipleks, enflamatuar demiyelinizan polinöropati benzeri kazanılmış demiyelinizan polinöropati olarak karşımıza çıkabilir $(6,7)$. Padovan ve ark. (8) yaptıkları çalışmada periferal sinir tutulumunun 65 yaş üzeri grupta daha sık olduğu bildirilmiştir. Başka bir çalışmada ise kranial/periferal nöropati açısından erken ve geç başlangıçlı SLE hastaları arasında farkılık gözlenmemiştir (2). Periferik nöropatinin patofizyolojisi tam olarak bilinmemekle birlikte anti-nöronal antikorlar, antikardiyolipin antikorlar ve immun kompleks birikimi suçlanmaktadır (6).

Tablo-1. Erken ve Geç Başlangıçlı Sistemik Lupus Eritematozus Genel Özellikleri (1).

\begin{tabular}{ccc}
\hline & Erken başlangıç & Geç başlangıç \\
\hline Yaş & $<50$ & $>50$ \\
\hline Sıklık & $\% 82-97$ & $\% 3-18$ \\
\hline $\begin{array}{c}\text { Kadın/ } \\
\text { Erkek }\end{array}$ & $9-14.4$ & $2.5-9$ \\
\hline $\begin{array}{c}\text { Klinik } \\
\text { Özellikler }\end{array}$ & $\begin{array}{c}\text { Sıklıkla mukokutanöz } \\
\text { semptomlar, Raynaud } \\
\text { özellikler, lupus nefriti }\end{array}$ & $\begin{array}{c}\text { Sıklıkla serözit } \\
\text { (perikardit, plörit), } \\
\text { akciğer tutulumu } \\
\text { (interstisyel } \\
\text { akciğer hastalı̆̆ı) }\end{array}$ \\
\hline $\begin{array}{c}\text { Sjögren } \\
\text { Sendromu }\end{array}$ & Az & Sık \\
\hline Seroloji & $\begin{array}{c}\text { Sıklıkla Anti-RNP, Anti-Sm } \\
\text { antikorları } \\
\text { hipokomplementemi }\end{array}$ & $\begin{array}{c}\text { Sıklıkla romatoid } \\
\text { faktör pozitifliği }\end{array}$ \\
\hline $\begin{array}{c}\text { Hastalık } \\
\text { şiddeti }\end{array}$ & Ciddi & Genellikle hafif \\
\hline
\end{tabular}

SLE'de normokrom normositer, mikrositer, hemolitik ve nadiren hipoplastik/aplastik anemi görülebilir. Hastamızda indirekt bilurubin, LDH yüksekliği, direkt Coombs testinin pozitif olması, düşük haptoglobulin düzeyi ve retikülositoz olması hemolitik anemiyi destekleyen laboratuvar bulgularıydı. Kemik iliği aspirasyonu yapılarak aplastik anemi ve pür kırmızı hücre aplazisi gibi hematopoietik yetmezlik sendromları ekarte edildi. Tanı anında hemolitik anemi, lökopeni ve trombositopeni gibi sitopenilerin sıklığı fazla görülmekle birlikte, erken ve geç başlangıçlı SLE hastaları arasındaki bulgular benzerdir (2). Steroid tedavisi sonrasında hemoglobin, retikülosit, indirekt bilurubin ve LDH düzeyleri düzelmeye başladı. İleri yaştaki olgularda ANA, anti-Ro, anti-La ve romatoid faktör yüksek oranda pozitif iken, anti-RNP ve hipokomplementemi ise daha az oranda görülür $(2,3)$. Bazı çalışmalarda anti-dsDNA antikorlarının geç başlangıçlı SLE hastalarında düşük oranda bulunurken, bazılarında ise yüksek ya da genç hastalarla benzer oranda olduğu bildirilmiştir $(8,9)$. Ancak, bu antikorlar ile organ hasarı arasında korelasyon bulunmamıştır. Bizim hastamızda ANA: 1/1000 titrede homojen paternde (nükleozom +, dsDNA ++), romatoid 
faktör normal sınırlarda ve C3: $77.6 \mathrm{mg} / \mathrm{dL}, \mathrm{C} 4: 11.5$ $\mathrm{mg} / \mathrm{dL}$ idi. Motor nöropati dışında herhangi bir organ tutulumuna dair bulgu da saptanmadı.

Tedavide kortikosteroid, antimalarial ve immunsuprese ilaçlar tedavide kullanılmakla birlikte ileri yaş başlangıcı olan SLE hastalarında düşük doz kortikosteroid ile hastalık kontrol altına alınmaktadır. Siklofosfomid gibi immunsuprese ajanlara ise daha az sıklıkla intiyaç duyulmaktadır $(2,3)$. Glukokortikoid ve immünsüprese ilaç kombinasyonu, nöropsikiyatrik bulguları olan şiddetli SLE vakalarında düşünülebilir. Sağ hemiparezi ve motor afazi ile başvuran iskemik inmeli SLE hastasında hastalık aktivitesinin düşük-doz glukokortikoid ve hidroksiklorokin ile kontrol altına alındığı bildirilmiştir (10). Sağ parietal lob infarktı olan ve SLE ilişkili antifosfolipid antikor sendromuna sahip başka bir vakada ise antikoagulan, düşük doz kortikosteroid ve hidroksiklorokin tedavisi ile takiplerinin 3. yılında yeni serebrovasküler olayla karşılaşılmamıştır (10). Bilateral alt ekstremitelerde güçsüzlük nedeniyle başvuran bizim hastamızda da metilprednizolon ve hidroksiklorokin ile klinik ve laboratuvar düzelme olmuştur.

Sonuç olarak; genç hastalar ile kıyaslandığında geç başlangıçlı SLE hastalarında klinik bulgular daha hafif ve sinsi seyretmektedir. Yaşlı hastalarda, ilaç etkileşimleri ve farmakokinetik değişiklikler dikkate alınmalıdır. Mortalite hastalığın kendisinden çok enfeksiyon, kardiyovasküler bozukluk, malignite ya da ilaçlara bağlı komplikasyonlar nedeniyle olmaktadır. Bu nedenle yaşlı hastalara optimal tedavi uygulanmalı ve yakın takip edilmelidir. Vaka sunumu ile sınırlı olsa da ileri yaşta motor nöropati ile başvuran hastalar klinik, laboratuvar ve serolojik bulgular ile birlikte SLE açısından değerlendirilmelidir.

\section{Kaynaklar}

1. Arnaud L, Mathian A, Boddaert J, et al. Late-onset systemic lupus erythematosus: Epidemiology, diagnosis and treatment. Drugs Aging 2012;29(3):181-9.

2. Tomic-Lucic A, Petrovic R, Radak-Perovic M, et al. Late-onset systemic lupus erythematosus: Clinical features, course, and prognosis. Clin Rheumatol 2013;32(7):1053-8.

3. Rovenský J, Tuchynová A. Systemic lupus erythematosus in the elderly. Autoimmun Rev 2008;7(3):235-9.

4. Song L, Kim YH, Chopra RK, et al. Age-related effects in T cell activation and proliferation. Exp Gerontol 1993;28(4-5):313-21.

5. Karoubi Nordon E, Hayem G, Mentres F, et al. Late onset systemic lupus erythematosus: A new approach. Lupus 2007;16(12):1011-4.

6. Navinan MR, Piranavan P, Akram AU, et al. Sensory neuronopathy complicating systemic lupus erythematosus: A case report. J Med Case Rep 2014;7(8):141.

7. Omdal R, Løseth S, Torbergsen T, et al. Peripheral neuropathy in systemic lupus erythematosus-a longitudinal study. Acta Neurol Scand 2001;103(6):386-91.

8. Padovan M, GovoniM, Castellino G, et al. Late onset systemic lupus erythematosus: No substantial differences using different cut off ages. Rheumatol Int 2007;27(8):735-41.

9. Wilson HA, Hamilton ME, Spyker DA, et al. Age influences the clinical and serological expression of systemic lupus erythematosus. Arthritis Rheum 1981;24(10):1230-5.

10. Bertsias GK, loannidis JP, Aringer M, et al. EULAR recommendations for the management of systemic lupus erythematosus with neuropsychiatric manifestations: Report of a task force of the EULAR standing committee for clinical affairs. Ann Rheum Dis 2010;69(12):2074-82. 